\title{
Elucidating tumor immunosurveillance and immunoediting: a comprehensive review
}

\section{Elucidando a imunovigilância e imunoedição tumoral: uma revisão abrangente}

Estela Vieira de Souza Silva ${ }^{1}$, Eduardo de Paula Nascente ${ }^{1}$ (D), Marina Pacheco Miguel $^{1}(\mathbb{D})$, Carlos Eduardo Fonseca Alves ${ }^{2}$ (D), Veridiana Maria Brianezi Dignani de Moura $^{1 *}$

'Universidade Federal de Goiás (UFG), Goiânia, Goiás, Brazil

¿Universidade Estadual Paulista (Unesp), Bauru, São Paulo, Brazil

*Correspondent-vdmoura@ufg.br

Received

April, 6, 2021.

Accepted

June 22, 2021

Published

July 23, 2021.

www.revistas.ufg.br/vet visit the website to get the how to cite in the article page.

\begin{abstract}
The action of the immune system against neoplastic diseases has become one of the main sources of research. The biological pathways of this system are known to contribute in limiting the progression and elimination of the tumor, and are delineated by concepts and mechanisms of immunosurveillance and immunoediting. Immunosurveillance is considered the process by which the immune system recognizes and inhibits the neoplastic process. The concept of immunoediting arises in the sense that immune system is able to shape the antigenic profile of the tumor due to selective pressure, based on the stages of tumor elimination, balance and evasion. The immune response occurs against tumor antigens and changes in the tumor microenvironment, involving different components of the innate immune system, such as T cells, natural Killer cells, B lymphocytes and macrophages. In this sense, knowing these concepts and understanding their respective mechanisms becomes essential in the investigation of new strategies for cancer prevention and cure. Thus, this review presents historical aspects and definitions of immunosurveillance and tumor immunoediting, with emphasis on its importance and applicability, such as on the different methods used in immunotherapy.

Keywords: immunocompetence; tumor immunology; immunotherapy; tumor progression; immune system
\end{abstract}

\footnotetext{
Resumo

A ação do sistema imunológico contra as enfermidades neoplásicas tem se tornado uma das principais fontes de pesquisa na atualidade. As vias biológicas desse sistema são conhecidas por contribuir na limitação da progressão e na eliminação do tumor, e são delineadas por conceitos e mecanismos de imunovigilância e imunoedição. A imunovigilância é considerada o processo pelo qual o sistema imunológico reconhece e inibe o processo neoplásico. O conceito de imunoedição surge no sentido de que o sistema imune é capaz de moldar o perfil antigênico do tumor devido à pressão seletiva, baseada nas etapas de eliminação,
} 
equilíbrio e evasão tumoral. A resposta imunológica ocorre contra antígenos tumorais e modificações do microambiente tumoral, envolvendo diferentes componentes do sistema imune inato, como células T, células natural Killer, linfócitos B e macrófagos. Nesse sentido, conhecer esses conceitos e compreender seus respectivos mecanismos torna-se essencial na investigação de novas estratégias de prevenção e combate ao câncer. Dessa forma, esta revisão apresenta aspectos históricos e definições de imunovigilância e imunoedição tumoral, com ênfase em sua importância e aplicabilidade, assim como aos diferentes métodos utilizados em imunoterapia.

Palavras-chave: imunocompetência; imunologia tumoral; imunoterapia; progressão tumoral; sistema imune

\section{Introduction}

The term immunity, from the Latin immunitas, has been used throughout history to elucidate the protection of an organism against pathogens, especially those of infectious origin. Cells and molecules with immunological properties were referred to as the immune system and the set of their actions against threats as immune response, being immunology, the branch of science developed for the study of these constituents. It became clear over time that the immune system responded not only to infectious agents but to any agent and/or substance considered as foreign to the organism, including tumor cells ${ }^{(1-4)}$.

In the mid-twentieth century, the discovery of new cell components of the immune system, such as natural killer (NK) lymphoid cells, as well as the deepening of studies involving neoplastic origin and development, led to the formulation of theories that correlate the performance of the immune system to the presence of tumor cells. The possibility that immune responses would be able to eradicate tumors altogether in its early development stages led to the concept of tumor immunosurveillance ${ }^{(5-8)}$.

Considering new findings, however, immunological processes triggered in the attempt to eliminate tumor cells, unlike the desired one, could have a powerful influence on the disease progression through indirect selective pressures. Therefore, the concept of immunosurveillance evolves tumor immunoediting, which is characterized by three stages: tumor cells elimination by the immune action, balance between the immune system and the remaining neoplastic components, and evasion of neoplasm to immune components ${ }^{(5,6,9)}$.

In view of the interrelationships of the immune system and neoplasms, research lines aiming at reestablishing the anti-tumor immunological effectiveness have been developed, such as immunotherapy protocols, which have presented promising results and have as a principle the inactivation of evasion mechanisms of tumor cells by immune cells $(7,10,11)$. Thus, this study aimed to present historical aspects and definitions 
of tumor immunosurveillance and immunoediting, highlighting their importance and implications.

\section{Tumor immunosurveillance - Mishaps throughout history}

In 1909, the scientist Paul Ehrlich proposed that natural defense mechanisms of an individual would be able to fight tumor cells and prevent neoplastic development. Ehrlich believed that with aging and cell renewal, the development of atypical cells would be normal, most of which would remain latent due to the ability of the body in blocking their evolution. However, the limited knowledge on the topic in this period and the limitation of experimentally proving this hypothesis led to its oblivion for years ${ }^{(6,12)}$.

In the early 1950s, Lewis Thomas and Frank MacFarlane Burnet suggested that tumor cell-specific antigens, referred to as neoantigens, were able of inducing an immune reaction against cancer, initiating the theory of tumor immunosurveillance ${ }^{(1,12)}$. According to Dunn et al. ${ }^{(5)}$, Burnet defined tumor immunosurveillance as follows: In large long-lived animals, like most of the warm-blooded vertebrates, inheritable genetic changes must be common in somatic cells and a proportion of these changes will represent a step toward malignancy. It is an evolutionary necessity that there should be some mechanism for eliminating and inactivating such potentially dangerous mutant cells and it is postulated that this mechanism is of immunological character.

Faced with the scientific and medical potential permeating immunosurveillance, in the following decades, numerous experiments were carried out to confirm or refute its assumptions. Grounded on a possible action of the immune system on tumor cells originating from the body itself, the majority of the experiments conducted between the $60 \mathrm{~s}$ and $80 \mathrm{~s}$ aimed to assess whether immunocompromised individuals would present a higher neoplastic incidence than those immunocompetent ${ }^{(5,6)}$. For this, in several studies immunosuppression was induced in mice through thymectomy, drug use or anti-lymphocyte agents, expecting further development of spontaneous or chemically induced tumors when compared to control mice with an efficient immune system. However, the results were contradictory since immunosuppressed and immunocompetent animals presented similar rates of tumor development ${ }^{(5,13)}$.

In the 1960s, mouse strains with gene mutations that result in deterioration or absence of the thymus (athymic nude mouse) ${ }^{(5,6)}$ were found to be naturally immunosuppressed due to their inability to generate mature $T$ lymphocytes. This finding has contributed to the study of immunosuppressive diseases, including the attempt to prove the immunosurveillance theory. However, the results remained similar to those of previous experiments, with no significant differences in neoplastic manifestation among immunocompromised and immunocompetent individuals. These results were abandoned since they did not contribute to the confirmation of immunosurveillance and other study strands on tumor immunology were considered $(5,13,14)$.

In the early 1970s, with the confirmation of the existence of NK lymphoid cells and the possibility of their role as immunosurveillance effector tools, it rekindled the 
scientific curiosity about the theory. However, the lack of knowledge and difficulty in understanding the action of NK cells soon led to the theory of immunosurveillance being ignored again ${ }^{(10,15,16)}$.

In the mid-1990s, two new discoveries were responsible for regaining interest in this theory. The first discovery was the endogenous production of interferon gamma (IFN-y), a protein capable of protecting the host against the growth of transplanted tumor cells, preventing the development of chemically induced tumors as well as spontaneous tumors ${ }^{(17)}$. The second discovery showed that certain non-perforin-producing mice strains were more susceptible to the development of chemically induced tumors when compared to strains that produced it. Perforins are cytotoxic components of cytotoxic granules of T lymphocytes (TL) and NK cells that play an important role in mediating cell death of different cell types, including tumor cells, by facilitating the entry of granzymes, cytolytic proteases, into their interior ${ }^{(18-20)}$.

Thus, it was clear at that time that components of the immune system were directly related to the primary control of neoplastic development ${ }^{(2,5)}$. The confirmation of tumor immunosurveillance, however, occurred in the late 1990s in research with mice bearing gene mutations that culminated in the absence of recombination activating genes 1 and 2 (RAG-1 and RAG-2). RAGs are essential to the processes of development and maturation of $B$ lymphocytes $(\mathrm{BL}), \mathrm{TL}$, and $\mathrm{NK}$, and their absence results in severe immunodeficiency ${ }^{(21,22)}$. Thus, experiments with strains of immunodeficient mice have shown, without any doubts, that lymphocytes were responsible for fighting and preventing induced and spontaneous neoplasms ${ }^{(6,23)}$.

Since then, other strains of test subjects with specific gene alterations have been created through the genetic manipulation that results in the deficiency of important components of the immune system. Studies with these animals confirmed the theory of tumor immunosurveillance and the importance of its constituents at genetic, chemical, and molecular levels ${ }^{(23)}$. Tumor immunosurveillance is currently defined as the process of monitoring, detecting, and eliminating tumor cells in the body before they originate neoplastic masses ${ }^{(1,13)}$.

\section{Tumor immunoediting - an evolutionary need}

After confirming the immunosurveillance, other research lines sought to answer the reason for the development of neoplasms in immunocompetent individuals since, in theory, their immunosurveillance mechanisms would be intact and functional. Thus, theories about the selection of low immunogenic tumor cell phenotypes, i.e. capable of stimulating a lower immune response, were postulated, being able to survive and proliferate $^{(12)}$ (Figure 1).

Experiments have shown that immunodeficient individuals present variants of tumor cells with a higher immunogenic potential when compared to immunocompetent individuals, demonstrating that the immune system of the host, in fact, exerts influence in the selection of tumor cells with a higher aptitude for survival. These cells are capable of resisting the immunological action of tumor suppression of the organism by various means, commonly referred to as tumor evasion mechanisms ${ }^{(5,13)}$. 


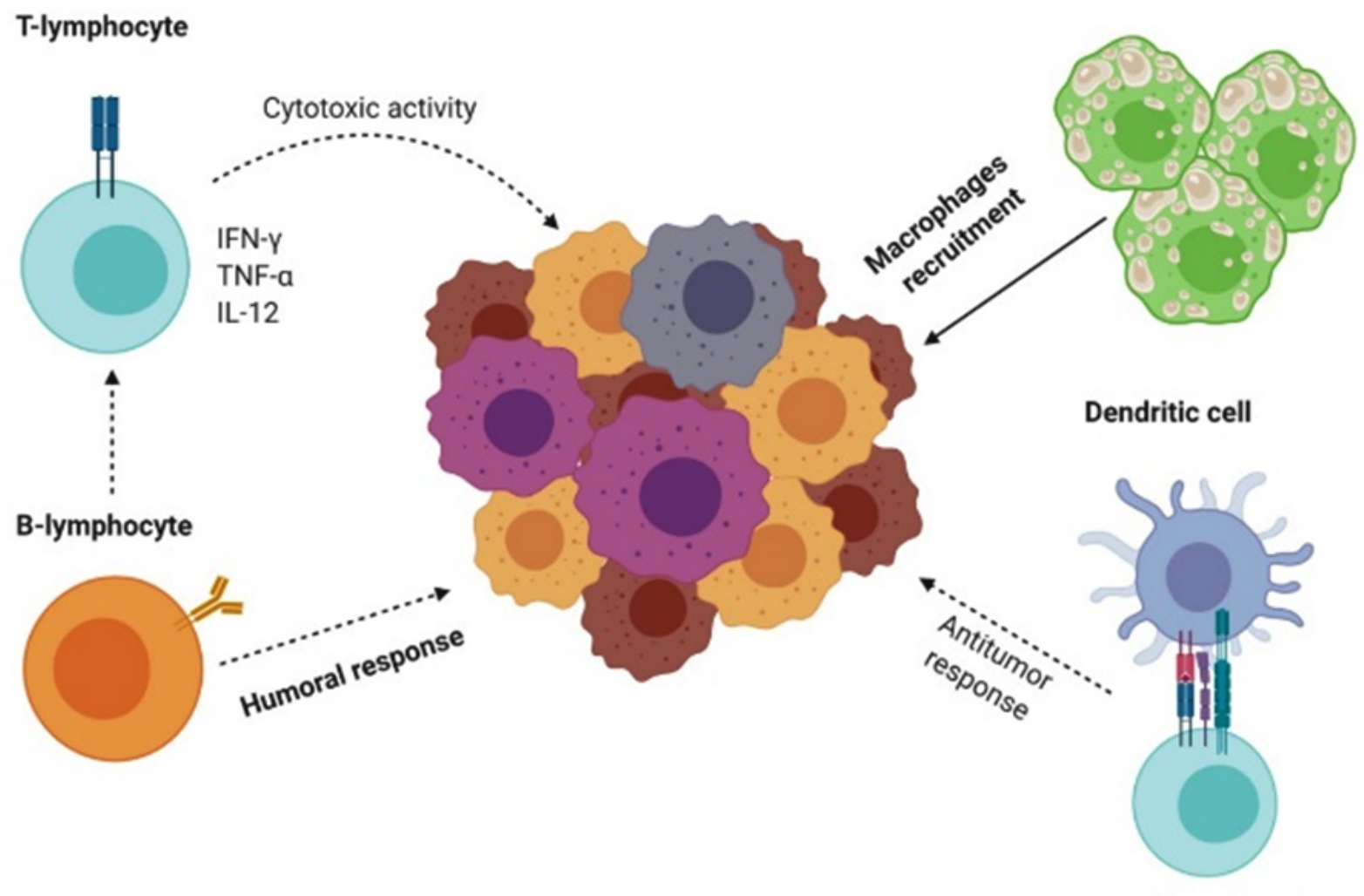

T-lymphocyte

Figure 1. Interaction among the tumor cells and different immune cells. Usually, tumor cells are heterogenic which allows tumor cells to scape from immunosurveillance. T-lymphocytes are responsible for the cytotoxic antitumor immunity and B-lymphocytes to humoral response. This humoral response is also associated with the presentation of antitumor antigens by dendritic cells and macrophages are recruit to phagocyte tumor cells.

Faced with the discovery that the immune system can both prevent and contribute to neoplastic development, the initial hypothesis of immunosurveillance, which included detection and control of tumor cells by the immune system, needed to be complemented. In this context, Gavin Dunn and Robert Schreiber proposed in 2002 the concept of tumor immunoediting, which covers aspects of immunosurveillance and process of tumor progression ${ }^{(13,24)}$. Therefore, tumor immunoediting represents the ambiguous aspect of the immune system against neoplasms, being this definition based on three stages referred to as "the three E of cancer immunoediting": elimination, equilibrium, and evasion ${ }^{(6,23,25)}$.

The elimination stage includes the concept and mechanisms of immunosurveillance, i.e. the immune system is mobilized to detect and eliminate tumor cells before the proliferation. These actions involve components of the innate immune system, such as NK cells, gamma delta lymphocytes (Ty $\delta)$, and macrophages, and those of the acquired immune system, such as CD8 ${ }^{+}$cytotoxic T lymphocytes (CTL), CD4 ${ }^{+}$helper T lymphocytes 


\section{$\left(T_{H}\right)$, regulatory $T$ lymphocytes (Treg), and $\mathrm{LB}^{(1,26,27)}$.}

Immune cell response can be initiated against tumor antigens and/or stromal changes occurring in the neoplastic microenvironment. Stromal remodeling induced by tumor cells induces the release of pro-inflammatory mediators, which, in association with the release of cytokines by tumor cells, promote the migration of inflammatory cell components to the site of neoplasm. Once recruited, NK cells, Ty $\delta$, and macrophages recognize molecules bound to neoplastic cells through binders such as NKG2D transmembrane proteins and CD1 glycolipid complexes ${ }^{(6,28,29)}$.

After recognition of tumor cells, IFN-y is released by lymphocytes, inducing the local production of chemokines, pro-inflammatory cytokines that promote the recruitment of more immune cells from the innate immune system. Among them, there are the macrophages, which, in turn, release interleukin-12(IL-12), which induces the recruitment of NK cells, promoting a positive feedback system. The increased IFN-y production activates cascades of associated events such as the release of mediators that prevent or reduce cell proliferation, as well as pro-apoptotic and angiostatic substances, processes that result in the elimination of a greater number of neoplastic cells. In addition, IFN-yactivated macrophages also release reactive oxygen species (ROS), lysosomal enzymes, nitric oxide (NO), and tumor necrosis factor-alpha (TNF-a), all with tumoricidal action ${ }^{(4)}$. There is an increase in the release of tumor antigens in the medium due to the death of tumor cells and subsequent activation of the acquired immune system(6).

In this sense, dendritic cells (DC) are activated by exposure to cytokines or interaction with NK cells and acquisition of antigens from the medium. Activated DC migrate to regional lymph nodes, where it induces $\mathrm{CD} 4^{+} \mathrm{TL}$ proliferation, which stimulate CD8 ${ }^{+}$ TL multiplication through the antigenic presentation by the major histocompatibility complex I (MHC-I), a DC-mediated process ${ }^{(27,30,31)}$.

The development of a specific immune response to neoplasm enables the host organism to eliminate the tumor in development. $C D 4^{+}$and $C D 8^{+}$cells identify tumor antigens expressed by tumor cells and promote their elimination through a series of mechanisms ${ }^{(1,6)}$. CD4 ${ }^{+}$TL cells produce interleukin-2 (IL-2) which, in association with interleukin-15 (IL-15) produced by organism cells, stimulate the production and maintenance of $\mathrm{CD}^{+} \mathrm{TL}$. They, in turn, can induce directly the death of tumor cells through perforin secretion and indirectly the production of high rates of IFN-y, processes that frequently occur concomitantly(19,32).

According to Dunn et $a^{(6)}$, the stage of elimination of cancer immunoediting is a continuous process, which needs to be repeated every time tumor cells present new antigens. Thus, it is understandable that with aging, and a consequent decline in the functions of the immune system, neoplasms prevail in elderly individuals.

In the equilibrium stage, variants of tumor cells that were able to survive to the elimination stage and the immune system of the host enter into a kind of dynamic equilibrium. Immune cells and their mediators, in attempt to eliminate the threat, exert a constant and powerful selective pressure on the tumor to contain it, yet it is unable to extinguish it. This is due to neoplastic heterogeneity due to genetic instability and epigenetic alterations, which are factors inherent to any neoplasm. Thus, neoplastic 
subclones less and less immunogenic, which eventually promote disease progression, are selected over time. However, the equilibrium stage is estimated to be the longest among the three of the immunoediting stages and may persist for years or even throughout an individual's lifetime ${ }^{(33,34)}$.

During the evasion stage, neoplastic variants with lower immunogenic potential acquire proliferative capacity and give continuity to the disease. For tumor cells to reach this stage, they must be able to overcome the potent immune barriers of the innate and acquired immune systems. This is possible by acquiring immuno-invasive strategies by neoplastic subclones with greater malignant potential and, consequently, survival and evolution ${ }^{(33,35)}$.

In the last two decades, much of the research related to oncology seeks to determine the molecular basis of mechanisms of tumor evasion developed by tumor cells. Currently, it is determined that direct and indirect mechanisms linked to these cells may be responsible for inhibiting antitumor immune responses related to the neoplastic microenvironment, neoplastic, inflammatory, mesenchymal, stromal, and vascular cells, as well as to the extracellular matrix, and soluble and signaling molecules ${ }^{(36,37)}$.

Cell constituents of the tumor microenvironment include $\mathrm{BL}$, $\mathrm{TL}$, Treg, NK cells, macrophages, granulocytes, mast cells, DC, eosinophils, and even immature myeloid cells, known as myeloid-derived suppressor cells (MDSC). In contrast to immune responses from pathogens, immune cells in a neoplastic environment have altered functions. In addition to the stromal components, these cells form a complex network of metabolic interactions that favor neoplastic proliferation and progression, being able of modulating evasion mechanisms ${ }^{(21,36,38)}$. According to Kerkar and Restifo( ${ }^{(36)}$, MDSC is able to differentiate into macrophages, DC, and endothelial cells in response to powerful proliferative stimuli induced by tumor cells. Like other immune cells activated by unconventional mechanisms, they acquire phenotypic alterations and differentiated functional profiles in order to lead TL suppression.

According to Zitvogel et al. ${ }^{(39)}$, the understanding of the neoplastic microenvironment and its functions has a direct impact on tumor immunosurveillance and immunoediting, as well as on immune responses induced by the different treatments in patients with neoplastic disease, which contributes to the prevention and treatment of cancer.

Every day new discoveries are made about the interaction between the immune system and tumor cells. The increasing potential of neoplasm treatment through immunological approaches has led to one of the areas currently studied by researchers linked to oncology, the immunotherapy. Considering that patients with neoplastic disease have, in one way or another, impairment of functions of their immune system, immunotherapy aims at modulating and increasing the antitumor performance of the immune system

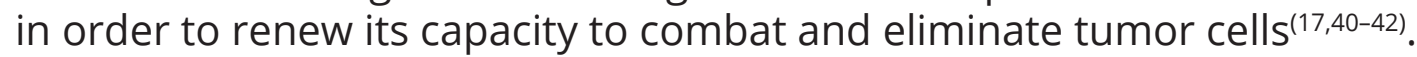

\section{Applications and perspectives of immunotherapy in oncology}

Immunotherapy has become one of the most promising strategies in the management 
of human and animal patients with cancer, since it results in long-lasting antitumor responses, and reduces the rates of metastases and recurrences ${ }^{(43)}$. Studies using dogs and other animal species as experimental models have validated the potential of immunotherapy against many neoplastic entities, such as bladder cancer(44), hemangiosarcoma ${ }^{(45)}$, transmissible venereal tumor ${ }^{(46)}$, oral melanoma ${ }^{(47)}$, lymphoma ${ }^{(48)}$, and mammary gland tumors ${ }^{(49)}$.

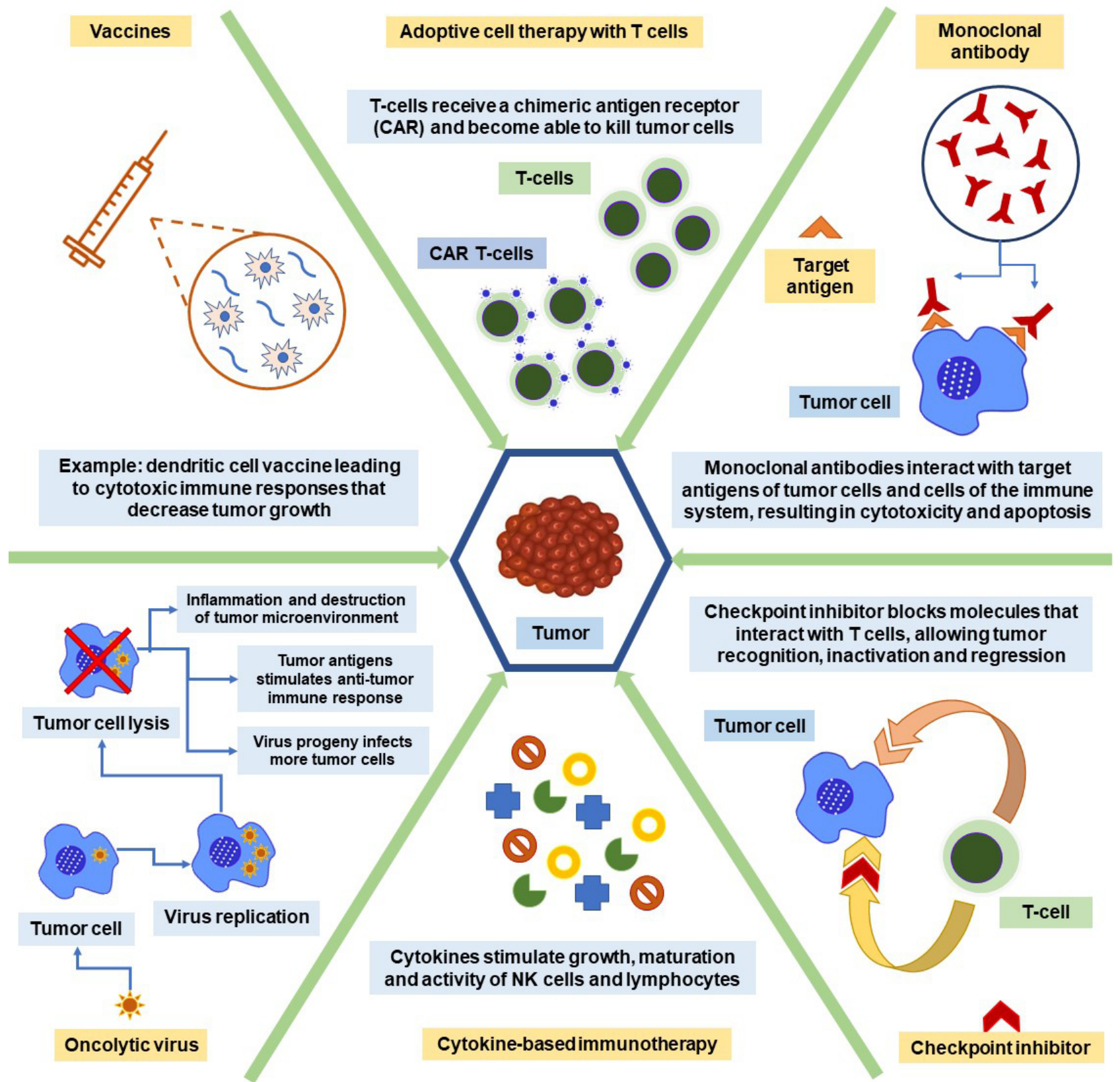

Figure 2. Examples of techniques and approaches used in immunotherapy applied to oncology. Vaccines; adoptive cell therapy with T cells; monoclonal antibodies capable of interacting with tumor antigens; checkpoint inhibitors which interact with T cells to promote tumor regression; cytokines to modulate the growth and maturation of different defense cells; and oncolytic viruses. 
Several techniques and therapeutic approaches in the field of immunotherapy have been investigated and applied in oncology, such as immunological modulation with the use of cytokines(50), checkpoint inhibitors, adoptive cell therapy with $T$ cells ${ }^{(51)}$, application of oncolytic viruses, vaccines ${ }^{(52)}$, and monoclonal antibodies ${ }^{(53)}$ (Figure 2). These, checkpoint inhibitors and cytokines are forms of immunotherapy that have the widest range of scientific investigation and application.

With regard to the checkpoint inhibitors, the commonly adopted strategies involve blocking molecules such as PD-1 / PD-L1 and CTLA4, which interact in association with T cells and result in tumor recognition, inactivation and regression ${ }^{(54,55)}$. In humans, there was a significant increase in the clinical impact of these strategies, mainly in terms of combined therapy with radiotherapy ${ }^{(56)}$ and chemotherapy ${ }^{(57)}$. In contrast, in veterinary medicine, clinical studies in animals are scarce due to the restriction of therapeutic antibodies, however, pilot tests performed by Maekawa et al. ${ }^{(53)}$, showed that checkpoint inhibitors can be effective in the treatment of oral melanoma and undifferentiated sarcomas in dogs.

The use of cytokines, mainly interferons and interleukins, has a different approach of checkpoint inhibitors, since they directly stimulate the growth, maturation and activity of cells from the immune system, such as NK cells and lymphocytes. Studies demonstrate that human interleukins, such as IL-12 and IL-15, generates a satisfactory antitumor response in canine patients ${ }^{(58,59)}$. These results corroborate the observations of Frampton et al. ${ }^{(60)}$, when investigating molecular signatures of regression of the transmissible venereal tumor in dogs. They observed that chemokines trigger the invasion of NK, CD8, and CD4 cells, helping the tumor regression and its elimination.

The adoptive cell therapy of T cells (ACT) has been shown to be efficient against malignant neoplasms of the hematopoietic system and melanomas in humans ${ }^{(61)}$. This technique involves the implantation of specific T lymphocytes in the patient organism, using lymphocytes from the autologous tumor or the peripheral blood, which are genetically modified and express specific anti-tumor T cell receptors (TCR) or chimeric antigen receptors (CAR) ${ }^{(62,63)}$.

The use of modified T cells to express CAR is the recent focus of many researchers since it is considered the most advanced clinical form of adoptive therapy for the treatment of lymphomas and leukemias in humans ${ }^{(64)}$. Likewise, Mata et al. ${ }^{(65)}$ showed, for the first time, the effectiveness of ACT when developed an efficient strategy in the generation of canine T cells expressing CAR. In addition, Panjwani et al. ${ }^{(66)}$ established, also for the first time, a model to evaluate therapy with T-CAR cells, using dogs with spontaneous diffuse B-cell lymphoma, with results that allow a better design of clinical studies in human beings.

In the same context, even with questions to be clarified, such as dose and application intervals, the administration of oncolytic viruses is seen as an interesting and plausible biological therapy in oncology. The virus can act directly, since it is capable of infect tumor cells and result in cell lysis, or, indirectly, stimulating and modulating the 
patient's immune system ${ }^{(67)}$. Several viral species have been evaluated in the treatment of canine neoplasms, such as transitional bladder cell carcinoma ${ }^{(68)}$, melanoma ${ }^{(69)}$, T-cell lymphoma ${ }^{(70)}$, and mast cell tumor ${ }^{(71)}$.

Adding, one of the oldest techniques involves vaccines, making it an attractive method due to its practicality and ease of preparation, using several primary sources, which resulted in the offer of several tumor vaccines for dogs, however, missing comprehensive clinical studies ${ }^{(72)}$. The use of autologous vaccines has shown similar and satisfactory responses when compared to conventional treatments, as evidenced by preliminary studies in canine patients with hepatocellular carcinoma, mast cell tumor, sarcoma of soft tissue ${ }^{(73)}$, metastatic hemangiosarcoma ${ }^{(74)}$, and osteosarcoma ${ }^{(75)}$.

However, experimental results with tumor vaccines have shown limited benefits, mainly related to nonspecific activation of the immune system and, in cases of solid tumors, there are reports of an exacerbated inflammatory reaction at the application site ${ }^{(72)}$. For this reason, new methodologies have been evaluated, such as the investigation of a checkpoint inhibitor vaccine for the treatment of canine melanoma ${ }^{(76)}$, and the development of a canine telomerase DNA vaccine ${ }^{(77,78)}$. These products were able to generate specific immune response, mainly with a significant increase in T cells.

Although in its initial phase, studies have evaluated the development of new monoclonal antibodies as potential immunotherapeutic agents for the treatment of cancer in dogs. Unlike medicine, in veterinary oncology the development of these antibodies is still incipient, since according to Klingemann ${ }^{(72)}$, there is a shortage of targetable antigens detected in animal species. These immunotherapeutic act as targeted therapy when interacting with target antigens of tumor cells and immune cell receptors, such as macrophages and NK cells, resulting in cytotoxic effects and apoptosis ${ }^{(79,80)}$.

The search for "caninized" antibodies has been the subject of investigations, as reported by Singer et al. ${ }^{(81)}$, which showed high specificity of the anti-EGFR antibody, which was effective in the recognition of canine tumor cells that overexpress EGFR. Lisowska

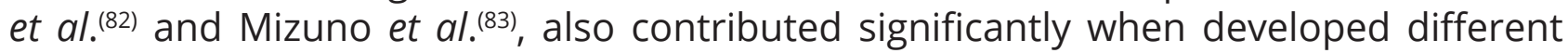
monoclonal antibodies capable of acting against canine lymphoma, with satisfactory results in vivo. In addition, therapeutic clinical trials with anti-podoplamine antibody in dogs with melanoma suggest a potential antitumor effect without important adverse effects ${ }^{(84)}$.

Unfortunately, both in medicine and inveterinary medicine, the results of immunotherapy are still limited to a minority of patients with certain types of neoplasia, with complex challenges to be clarified, aiming at better management of immunotherapy in cancer patients ${ }^{(52)}$. For example, cytokine therapy can trigger toxic conditions that result in sepsis-like syndrome and, in severe cases, multiple organ failure ${ }^{(34)}$. Adding, there are intrinsic and extrinsic factors of the tumor cell that result in primary, adaptive and acquired resistance to immunotherapy ${ }^{(85)}$.

Due to these limitations, additional techniques with the use of nanotechnology are also investigated, mainly associated with anti-tumor vaccines and the tumor microenvironment modulation process ${ }^{(43)}$. Thus, nanoparticles, such as liposomes, 
dendrimers, micelles, polymer nanoparticles, nanotubes, and inorganic nanoparticles, are a valuable tool for immunotherapy, since they are capable of directing the therapeutic agent to the tumor ${ }^{(86-88)}$ (Figure 3).

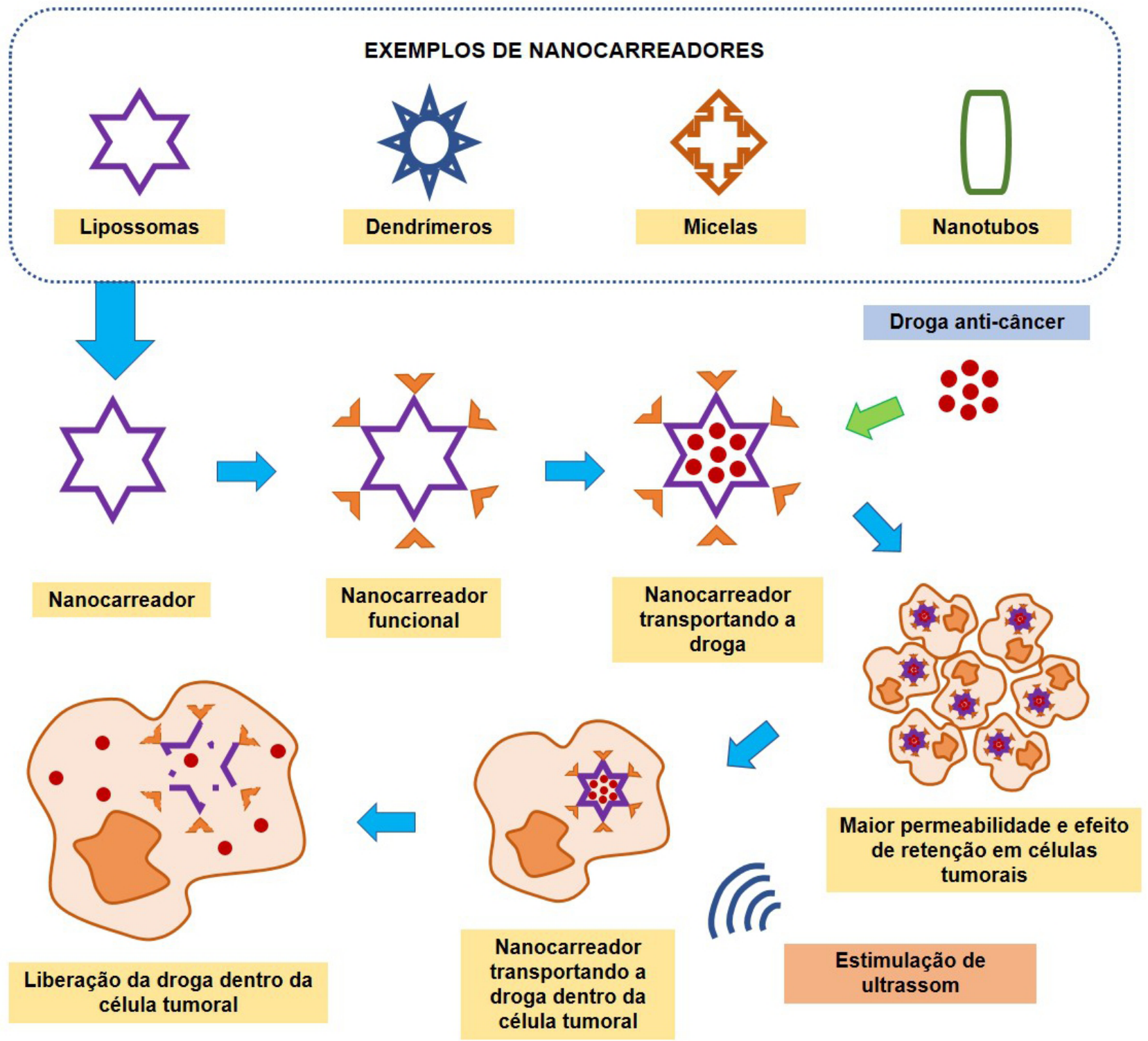

Figura 3. Nanotecnologia associada à imunoterapia para uso em oncologia. Diferentes nanopartículas, como lipossomas, dendrímeros, micelas e nanotubos, são utilizadas como carreadores de diferentes drogas antitumorais de forma direcionada. Essas moléculas permitem maior permeabilidade e efeito de retenção nas células tumorais, e, após estimulação, liberação do fármaco antitumoral e lise das células tumorais.

Despite recent and strict studies, the use of nanoparticles in association with immunotherapy was reported by Chariou et al. ${ }^{(89)}$, who presented, in a mouse melanoma model, nanoparticles with virus-based oncolytic potential. Still, in a model of rectal carcinoma in mice ${ }^{(90)}$ and in spontaneous canine glioma ${ }^{(91)}$, the combination 
of nanoparticles with immunotherapeutic agents shows that nanomedicine directed to the tumor microenvironment inhibits immunosuppressive cells and significantly enhances immunotherapeutic agents.

Thus, its important understand that events that integrate tumor immunology are not simple, and it requires knowledge of the immunological bases, its constituents, functions and molecular interactions, as well as the general neoplastic physiopathology and each tumor variant. Neoplasms are unique and unstable organisms, with cells having different degrees of heterogeneity, forming different microenvironments, with which they interact and trigger specific reactions. The understanding of immunosurveillance and neoplastic immunoediting is, therefore, one of the main starting points for understanding of complex and not fully clarified concepts, but essential in the search for preventive and therapeutic tools aimed at neoplastic diseases.

\section{Final Considerations}

The evolution of tumor immunology, leading to the deepening of the events that are part of immunosurveillance and immunoediting processes, contributes significantly to a better understanding of the mechanisms associated with neoplastic development and progression. Thus, the detailing of interactions between components of the immune system and tumor cells has an important impact on the prevention and treatment of cancer since it allows the development of more effective counterattack strategies.

\section{Conflict of interests}

The authors declare no conflict of interest.

\section{References}

1. Abbas AK, Lichtman A, Pillai S. Cellular and Molecular Immunology. 9th ed. Philadelphia: Elsevier Saunders; 2017. 608 p.

2. Galon J, Angell HK, Bedognetti D, Marincola FM. The Continuum of Cancer Immunosurveillance: Prognostic, Predictive, and Mechanistic Signatures. Immunity. 2013;39(1):11-26.

3. Mackay IR. Travels and travails of autoimmunity: A historical journey from discovery to rediscovery. Autoimmun Rev. 2010;9(5):251-258.

4. Male DK, Peebles RS., Male V. Immunology. 9th ed. Philadelphia: Elsevier Saunders; 2020.432 p.

5. Dunn GP, Bruce AT, Ikeda H, Old LJ, Schreiber RD. Cancer immunoediting: From immunosurveillance to tumor escape. Nat Immunol. 2002;3(11):991-998.

6. Dunn GP, Old LJ, Schreiber RD. The three Es of cancer immunoediting. Annu Rev Immunol. 2004;22:32960.

7. Garg AD, Agostinis P. Cell death and immunity in cancer: From danger signals to mimicry of pathogen defense responses. Immunol Rev. 2017;280(1):126-148.

8. Kim R, Emi M, Tanabe K. Cancer immunoediting from immune surveillance to immune escape. Immunology. 2007;121(1):1-14. 
Elucidating tumor immunosurveillance and immunoediting: a comprehensive review Silva E V S et al.

9. Bhatia A, Kumar Y. Cellular and molecular mechanisms in cancer immune escape: A comprehensive review. Expert Rev Clin Immunol. 2014;10(1):41-62.

10. Fehniger TA, Cooper MA. Harnessing NK Cell Memory for Cancer Immunotherapy. Trends Immunol. 2016;37(12):877-888.

11. Spitzer MH, Carmi Y, Reticker-Flynn NE, Kwek SS, Madhireddy D, Martins MM, et al. Systemic Immunity Is Required for Effective Cancer Immunotherapy. Cell. 2017;168(3):487-502.

12. Ribatti D. The concept of immune surveillance against tumors: The first theories. Oncotarget. 2015;8(5):7175-7180.

13. Mahmoud F, Shields B, Makhoul I, Avaritt N, Wong HK, Hutchins LF, et al. Immune surveillance in melanoma: From immune attack to melanoma escape and even counterattack. Cancer Biol Ther. 2017;18(7):451-469.

14. Jinushi $M$, Komohara $Y$. Tumor-associated macrophages as an emerging target against tumors: Creating a new path from bench to bedside. Biochim Biophys Acta - Rev Cancer. 2015;1855(2):123-130.

15. Böttcher JP, Bonavita E, Chakravarty P, Blees H, Cabeza-Cabrerizo M, Sammicheli S, et al. NK Cells Stimulate Recruitment of CDC1 into the Tumor Microenvironment Promoting Cancer Immune Control. Cell. 2018;172(5):1022-1037.

16. Dyck L, Lynch L. New Job for NK Cells: Architects of the Tumor Microenvironment. Immunity. 2018;48(1):9-11.

17. Hunter KW, Amin R, Deasy S, Ha NH, Wakefield L. Genetic insights into the morass of metastatic heterogeneity. Nat Rev Cancer. 2018;18(4):211-223.

18. Cullen SP, Brunet M, Martin SJ. Granzymes in cancer and immunity. Cell Death Differ. 2010;17(4):616623.

19. Law RHP, Lukoyanova N, Voskoboinik I, Caradoc-Davies T, Baran K, Dunstone MA, et al. The structural basis for membrane binding and pore formation by lymphocyte perforin. Nature. 2010;468(7322):447451.

20. Takeda K, Nakayama M, Hayakawa Y, Kojima Y, Ikeda H, Imai N, et al. IFN-y is required for cytotoxic T cell-dependent cancer genome immunoediting. Nat Commun [Online]. 2017 [Cited 2021 Feb 15];8:14607. Available from: https://doi.org/10.1038/ncomms14607. English.

21. Notarangelo LD, Kim MS, Walter JE, Lee YN. Human RAG mutations: Biochemistry and clinical implications. Nat Rev Immunollogy. 2016;16(4):234-246.

22. Ru H, Mi W, Zhang P, Alt FW, Schatz DG, Liao M, et al. DNA melting initiates the RAG catalytic pathway. Nat Struct Mol Biol. 2018;25(8):732-742.

23. Efremova M, Rieder D, Klepsch V, Charoentong P, Finotello F, Hackl H, et al. Targeting immune checkpoints potentiates immunoediting and changes the dynamics of tumor evolution. Nat Commun [Online]. 2018 [Cited $2021 \mathrm{Feb} 20] ; 9(1): 32$. Available from: https://doi.org/10.1038/s41467-017-02424-0. English.

24. Zitvogel L, Pietrocola F, Croemer G. Nutrition, inflammation and cancer. Nat Immunollogy. 2017;18(8):843-850.

25. Mohammad RM, Muqbil I, Lowe L, Yedjou C, Hsu HY, Al. E. Broad targeting of resistance to apoptosis in cancer. Semin Cancer Biol. 2015;35:78-103.

26. Morrow ES, Roseweir A, Edwards J. The role of gamma delta T lymphocytes in breast cancer: a review. Transl Cancer Res. 2019;203:88-96.

27. Palucka AK, Coussens LM. The Basis of Oncoimmunology. Cell. 2016;164(6):1233-1247.

28. Lanier LL. NKG2D receptor and its ligands in host defense. Cancer Immunol Res. 2015;3(6):575-582. 
Elucidating tumor immunosurveillance and immunoediting: a comprehensive review

Silva E V S et al.

29. Nagarsheth N, Wisha MS, Zou W. Chemokines in the cancer microenvironment and their relevance in cancer immunotherapy. Nat Rev Immunollogy. 2017;17(9):559-572.

30. Ayroldi E, Cannarile L, Delfino DV, Riccardi C. A dual role for glucocorticoid-induced leucine zipper in glucocorticoid function: Tumor growth promotion or suppression? review-article. Cell Death Dis. [Online]. 2018 [Cited 2021 Mar 12];9(5):463. Available from: https://doi.org/10.1038/s41419-018-0558-1. English.

31. Strioga M, Schijns V, Powell Jr DJ, Pasukoniene, V. Dobrovolskiene N, Michalek K. Dendritic cells and their role in tumor immunosurveillance. Innate Immun. 2017;19(1):98-111.

32. Yao Y, Chen S, Cao M, Fan X, Yang T, Huang Y, et al. Antigen-specific CD8+ T cell feedback activates NLRP3 inflammasome in antigen-presenting cells through perforin. Nat Commun [Online]. 2017 [Cited 2021 Feb 22];8:e15402. Available from: https://doi.org/ 10.1038/ncomms15402. English.

33. Caswell DR, Swanton C. The role of tumour heterogeneity and clonal cooperativity in metastasis, immune evasion and clinical outcome. BMC Med [Onlinel. 2017 [Cited 2021 Jan 30];15(1):1-9.Available from: https://doi.org/10.1186/s12916-017-0900-y. English.

34. Valent P, Bonnet D, Wöhrer S, Andreeff M, Copland M, Chomienne C, et al. Heterogeneity of neoplastic stem cells: Theoretical, functional, and clinical implications. Cancer Res. 2013;73:1037-1045.

35. Mohme M. Circulating and disseminated tumour cells-mechanisms of immune surveillance and escape. Nat Rev Clin Oncol. 2017;14(3):155-167.

36. Kerkar SP, Restifo NP. Cellular constituents of immune escape within the tumor microenvironment. Cancer Res. 2012;72(13):3125-3130.

37. Casey SC, Amedei A, Aquilano K, Azmi AS, Benencia F, Bhakta D, et al. Cancer prevention and therapy through the modulation of the tumor microenvironment. Semin Cancer Biol. 2015;35(Suppl):S199-223.

38. Chiarugi P, Cirri P. Metabolic exchanges within tumor microenvironment. Cancer Lett. 2016;380(1):272280.

39. Zitvogel L, Ayyoub M, Routy B, Kroemer G. Microbiome and Anticancer Immunosurveillance. Cell. 2016;165(2):276-287.

40. Finn OJ. Immuno-oncology: Understanding the function and dysfunction of the immune system in cancer. Ann Oncology [Online]. 2012 [Cited 2021 Mar 21];23(suppl8):viii6-9. Available from: https://doi. org/10.1093/annonc/mds256. English

41. Pancione M, Giordano G, Remo A, Febbraro A, Sabatino L, Manfrin E, et al. Immune escape mechanisms in colorectal cancer pathogenesis and liver metastasis. J Immunol Res.[Online]. 2014 [Cited 2021 Feb 24];2014:e686879. Available from: https://doi.org/10.1155/2014/686879. English.

42. Park YJ, Kuen DS, Chung Y. Future prospects of immune checkpoint blockade in cancer: from response prediction to overcoming resistance. Exp Mol Med.[Online]. 2018 [Cited 2020 Dec 22];50(8):109. Available from: https://doi.org/10.1038/s12276-018-0130-1. English.

43. Song W, Musetti SN, Huang L. Nanomaterials for cancer immunotherapy. Biomaterials. 2017;148:1630.

44. Maeda S, Murakami K, Inoue A, Yonezawa T, Matsuki N. CCR4 blockade depletes regulatory T cells and prolongs survival in a canine model of bladder cancer. Cancer Immunol Res. 2019;7(7):1175-1187.

45. Konduri V, Halpert MM, Baig YC, Coronado R, Rodgers JR, Levitt JM, et al. Dendritic cell vaccination plus low-dose doxorubicin for the treatment of spontaneous canine hemangiosarcoma. Cancer Gene Ther. 2019;26(9-10):282-291.

46. Ramos-Zayas Y, Franco-Molina MA, Hernádez-Granados AJ, Zárate-Triviño DG, Coronado-Cerda

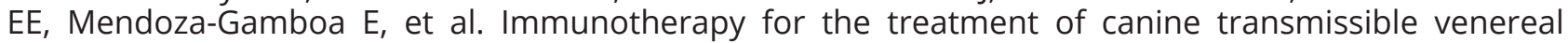
tumor based in dendritic cells pulsed with tumoral exosomes. Immunopharmacol Immunotoxicol. 2019;41(1):48-54. 
Elucidating tumor immunosurveillance and immunoediting: a comprehensive review Silva E V S et al.

47. Hoopes PJ, Wagner RJ, Duval K, Kang K, Gladstone DJ, Moodie KL, et al. Treatment of Canine Oral Melanoma with Nanotechnology-Based Immunotherapy and Radiation. Mol Pharm. 2018;15(9):37173722.

48. O'Connor CM, Sheppard S, Hartline CA, Huls H, Johnson M, Palla SL, et al. Adoptive T-cell therapy improves treatment of canine non-Hodgkin lymphoma post chemotherapy. Scientific Reports [Online]. 2012 [Cited 2021 Jan 10];2(1):249. Available from: https://doi.org/10.1038/srep00249. English.

49. Li Y, Sun Y, Kulke M, Hechler T, Van der Jeught K, Dong T, et al. Targeted immunotherapy for HER2low breast cancer with 17p loss. Sci Transl Med. [Online] 2021[Cited 2021 Mar 18];13(580):eabc6894. Available from: https://doi.org/10.1126/scitranslmed.abc6894. English.

50. Krieg C, Létourneau S, Pantaleo G, Boyman O. Improved IL-2 immunotherapy by selective stimulation of IL-2 receptors on lymphocytes and endothelial cells. Proc Natl Acad Sci U S A. 2010;107(26):1190611911.

51. Borst J, Ahrends T, Bąbała N, Melief CJM, Kastenmüller W. CD4+ T cell help in cancer immunology and immunotherapy. Nat Rev Immunol. 2018;18(10):635-647.

52. Kennedy LB, Salama AKS. A review of cancer immunotherapy toxicity. CA Cancer J Clin. 2020;70(2):86104.

53. Maekawa N, Konnai S, Takagi S, Kagawa Y, Okagawa T, Nishimori A, et al. A canine chimeric monoclonal antibody targeting PD-L1 and its clinical efficacy in canine oral malignant melanoma or undifferentiated sarcoma. Scientific Reports [Online]. 2017 [Cited 2021 Mar 18];7(1):1-12. Available from: https://doi. org/10.1038/s41598-017-09444-2. English.

54. Alsaab HO, Sau S, Alzhrani RT, Bhise K, Kashaw SK, lyer AK. PD-1 and PD-L1 checkpoint signaling inhibition for cancer immunotherapy: mechanism, combinations, and clinical outcome. Frontiers in Pharmacology [Online]. 2017 [Cited 2021 Feb 19]; 8:561. Available from: https://doi.org/10.3389/ fphar.2017.00561. English.

55. Vargas F, Furness AJS, Litchfield K, Joshi K, Rosenthal R, Ghorani E, et al. Fc Effector Function Contributes to the Activity of Human Anti-CTLA-4 Antibodies. Cancer Cell [Online]. 2018 [Cited 2021 Mar 02];33(4):649663.e4. Available from: https://doi.org/10.1016/j.ccell.2018.02.010. English.

56. Park SS, Dong H, Liu X, Harrington SM, Krco CJ, Grams MP, et al. PD-1 restrains radiotherapy-induced abscopal effect. Cancer Immunol Res. 2015;3(6):610-619.

57. Tang J, Shalabi A, Hubbard-Lucey VM. Comprehensive analysis of the clinical immuno-oncology landscape. Ann Oncol. 2018;29(1):84-91.

58. Pavlin D, Cemazar M, Sersa G, Tozon N. IL-12 based gene therapy in veterinary medicine. J Transl Med. [Online]. 2012 [Cited 2021 Mar 21];10(1):234. Available from: https://doi.org/10.1186/1479-5876-10-234. English.

59. Judge SJ, Darrow MA, Thorpe SW, Gingrich AA, O'Donnell EF, Bellini AR, et al. Analysis of tumor-infiltrating NK and T cells highlights IL-15 stimulation and TIGIT blockade as a combination immunotherapy strategy for soft tissue sarcomas. J Immunother Cancer [Online]. 2020 [Cited 2021 Feb 17];8:e001355. Available from: https://doi.org/10.1136/jitc-2020-001355. English.

60. Frampton D, Schwenzer H, Marino G, Butcher LM, Pollara G, Kriston-Vizi J, et al. Molecular Signatures of Regression of the Canine Transmissible Venereal Tumor. Cancer Cell. 2018;33(4):620-633.

61. Bujak JK, Pingwara R, Nelson MH, Majchrzak K. Adoptive cell transfer: New perspective treatment in veterinary oncology. Acta Vet Scand. [Online]. 2018 [Cited 2021 Feb 17];60(1):60. Available from: https:// doi.org/10.1186/s13028-018-0414-4. English.

62. Rosenberg SA, Restifo NP, Yang JC, Morgan RA, Dudley ME. Adoptive cell transfer: A clinical path to effective cancer immunotherapy. Nat Rev Cancer. 2008;8(4):299-308.

63. Raval RR, Sharabi AB, Walker AJ, Drake CG, Sharma P. Tumor immunology and cancer immunotherapy: 
Elucidating tumor immunosurveillance and immunoediting: a comprehensive review Silva E V S et al.

Summary of the 2013 SITC primer. J Immunother Cancer. 2014;2(1):2-14.

64. Tokarew N, Ogonek J, Endres S, von Bergwelt-Baildon M, Kobold S. Teaching an old dog new tricks: next-generation CAR T cells. Br J Cancer. 2019;120(1):26-37.

65. Mata M, Vera JF, Gerken C, Rooney CM, Miller T, Pfent C, et al. Toward immunotherapy with redirected T cells in a large animal model: Ex vivo activation, expansion, and genetic modification of canine T cells. J Immunother. 2014;37(8):407-415.

66. Panjwani MK, Atherton MJ, MaloneyHuss MA, Haran KP, Xiong A, Gupta M, et al. Establishing a model system for evaluating CAR T cell therapy using dogs with spontaneous diffuse large B cell lymphoma. Oncoimmunology [Online]. 2020 [Cited 2021 Feb 17];9(1):1676615.Available from: https:// doi.org/10.1080/2162402X.2019.1676615. English.

67. Sánchez D, Cesarman-Maus G, Amador-Molina A, Lizano M. Oncolytic viruses for canine cancer treatment. Cancers [Online]. 2018 [Cited 2021 Feb 25]; 10(11):404. Available from: https://doi.org/10.3390/ cancers10110404. English.

68. lizuka K, Shoji K, Fujiyuki T, Moritoh K, Tamura K, Yoshida A, et al. Antitumor activity of an oncolytic measles virus against canine urinary bladder transitional cell carcinoma cells. Res Vet Sci. 2020;133:313317.

69. Igase M, Shibutani S, Kurogouchi Y, Fujiki N, Hwang CC, Coffey M, et al. Combination Therapy with Reovirus and ATM Inhibitor Enhances Cell Death and Virus Replication in Canine Melanoma. Mol Ther Oncolytics. 2019;15:49-59.

70. Naik S, Galyon GD, Jenks NJ, Steele MB, Miller AC, Allstadt SD, et al. Comparative oncology evaluation of intravenous recombinant oncolytic vesicular stomatitis virus therapy in spontaneous canine cancer. Mol Cancer Ther. 2018;17(1):316-326.

71. Ilyinskaya GV, Mukhina EV, Soboleva AV, Matveeva OV, Chumakov PM. Oncolytic sendai virus therapy of canine mast cell tumors (A pilot study). Front Vet Sci. [Online]. 2018 [Cited 2021 Feb 16];5:116. Available from: https://doi.org/10.3389/fvets.2018.00116. English.

72. Klingemann H. Immunotherapy for Dogs: Running Behind Humans. Front Immunol. [Online]. 2018 [Cited 2021 Feb 19];9:133. Available from: https://doi.org/10.3389/fimmu.2018.00133. English.

73. Goodrich RP, Weston J, Hartson L, Griffin L, Guth A. Pilot Acute Safety Evaluation of Innocell ${ }^{\mathrm{TM}}$ Cancer Immunotherapy in Canine Subjects.] Immunol Research [Online]. 2020 [Cited 2021 Mar 01];2020:7142375. Available from: https://doi.org/10.1155/2020/7142375. English.

74. Lucroy MD, Clauson RM, Suckow MA, El-Tayyeb F, Kalinauskas A. Evaluation of an autologous cancer vaccine for the treatment of metastatic canine hemangiosarcoma: a preliminary study. BMC Vet Research [Online]. 2020 [Cited 2021 Mar 12];16(1):447. Available from: https://doi.org/10.1186/s12917020-02675-y. English.

75. Musser ML, Berger EP, Tripp CD, Clifford CA, Bergman PJ, Johannes CM. Safety evaluation of the canine osteosarcoma vaccine, live Listeria vector. Vet Comp Oncol. 2021;19(1):92-98.

76. Kurupati RK, Zhou X, Xiang Z, Keller LH, Ertl HCJ. Safety and immunogenicity of a potential checkpoint blockade vaccine for canine melanoma. Cancer Immunol Immunother. 2018;67(10):1533-1544.

77. Impellizeri JA, Gavazza A, Greissworth E, Crispo A, Montella M, Ciliberto G, et al. Tel-eVax: A genetic vaccine targeting telomerase for treatment of canine lymphoma. J Transl Med. [Online] 2018 [Cited 2021 Feb 19];16(1):349. Available from: https://doi.org/10.1186/s12967-018-1738-6. Englidh.

78. Thalmensi J, Pliquet E, Liard C, Chamel G, Kreuz C, Bestetti T, et al. A DNA telomerase vaccine for canine cancer immunotherapy. Oncotarget. 2019;10(36):3361-3372.

79. Chung S, Lin YL, Reed C, Ng C, Cheng ZJ, Malavasi F, et al. Characterization of in vitro antibody-dependent cell-mediated cytotoxicity activity of therapeutic antibodies - Impact of effector cells. J Immunol Methods. 2014;407:63-75. 
80. Kimiz-Gebologlu I, Gulce-Iz S, Biray-Avci C. Monoclonal antibodies in cancer immunotherapy. Molecular Biology Reports. 2018; 45:2935-2940.

81. Singer J, Jensen-Jarolim E. IgE-based immunotherapy of cancer: Challenges and chances. Allergy Eur J Allergy Clin Immunol. 2014;69(2):137-149.

82. Lisowska M, Pawlak A, Kutkowska J, Hildebrand W, Ugorski M, Rapak A, et al. Development of novel monoclonal antibodies to dog leukocyte antigen DR displaying direct and immune-mediated cytotoxicity toward canine lymphoma cell lines. Hematol Oncol. 2018;36(3):554-560.

83. Mizuno $T$, Kato $Y$, Kaneko MK, Sakai $Y$, Shiga $T$, Kato $M$, et al. Generation of a canine anti-canine CD20 antibody for canine lymphoma treatment. Scientific Reports [Online]. 2020 [Cited 2021 Mar 11];10(1):11476. Available from: https://doi.org/10.1038/s41598-020-68470-9. English.

84. Kamoto S, Shinada M, Kato D, Yoshimoto SI, Tsuboi M, Yoshitake R, et al. Phase I/II Clinical Trial of the Anti-Podoplanin Monoclonal Antibody Therapy in Dogs with Malignant Melanoma. Cells [Online]. 2020 [Cited 2021 Mar 12];9(11):2529. Available from: https://doi.org/10.3390/cells9112529. English.

85. Sharma P, Hu-Lieskovan S, Wargo JA, Ribas A. Primary, Adaptive, and Acquired Resistance to Cancer Immunotherapy. Cell. 2017;168(4):707-723.

86. Parhi P, Mohanty C, Sahoo SK. Nanotechnology-based combinational drug delivery: An emerging approach for cancer therapy. Drug Discovery Today. 2012; 17 (17-18):1044-1052.

87. Kumari P, Ghosh B, Biswas S. Nanocarriers for cancer-targeted drug delivery. Journal of Drug Targeting. 2016; 24(3):179-191.

88. Fontana F, Liu D, Hirvonen J, Santos HA. Delivery of therapeutics with nanoparticles: what's new in cancer immunotherapy. Wiley Interdisciplinary Reviews: Nanomedicine and Nanobiotechnology [Online]. 2017 [Cited 2021 Feb 16]; 9(1):e1421. Available from: https://doi.org/10.1002/wnan.1421. English.

89. Chariou PL, Beiss V, Ma Y, Steinmetz NF. In situ vaccine application of inactivated CPMV nanoparticles for cancer immunotherapy . Mater Adv. 2021;2(5):1644-1656.

90. Chiang CS, Lin YJ, Lee R, Lai Y., Cheng HW, Hsieh CH, et al. Combination of fucoidan-based magnetic nanoparticles and immunomodulators enhances tumour-localized immunotherapy. Nat Nanotechnol. 2018;13(8):746-754.

91. Sayour EJ, Grippin A, De Leon G, Stover B, Rahman M, Karachi A, et al. Personalized Tumor RNA Loaded Lipid-Nanoparticles Prime the Systemic and Intratumoral Milieu for Response to Cancer Immunotherapy. Nano Lett. 2018;18(10):6195-6206. 